\title{
O obrotach gwiazd głupszych
}

\author{
Witold Wachowski \\ Ośrodek Badań Filozoficznych w Warszawie \\ w[]avant.edu.pl \\ Otrzymano i zaakceptowano: czerwiec 2014; opublikowano: lato 2014.
}

\author{
A kto wymyślit, \\ że gwiazdy gtupsze \\ krążą dokoła mądrzejszych? \\ (Białoszewski 1956/1987: 60)
}

\begin{abstract}
Abstrakt
Tekst stanowi wprowadzenie do artykułu Davida Kirsha „Myślenie za pomocą reprezentacji zewnętrznych” wpisujące badania nad tytułowymi reprezentacjami w szerszy kontekst dyskusji nad znaczeniem pozaneuronalnej sfery poznania, także z perspektywy innej niż tego autora.
\end{abstract}

Słowa kluczowe: reprezentacje zewnętrzne; poznanie rozproszone; system poznawczy; afordancja; interakcja; eksternalizm; Kirsh.

\section{Wprowadzenie}

Gdy zagadnąć młodego polskiego adepta kognitywistyki, co właściwie stanowi faktyczny przedmiot badań w jego dziedzinie, najczęściej i bez wahania wskaże na mózg. Niezwykle złożony organ, cud ewolucji, wcielenie jaźni, twierdza tajemnic nad tajemnice, a $\mathrm{z}$ drugiej strony - uzbrojeni w skanery (neuro)rycerze, którzy szturmują ową twierdzę. Misja szlachetna, wizja fascynująca, bo i nie sposób podważyć zasług neuronauki. Ale być może warto też zrobić kilka kroków dla osiągnięcia pewnego dystansu, by wyrazić zdumienie również nad różnorodną strukturą i nieustannie bodźcującą zmiennością otaczającego nas świata, w którym mózg nie tylko wyewoluował, ale wciąż się reorganizuje w ramach swojej plastycznej natury. A ile są warte dociekania nad wkładem owego otoczenia w badania nad poznaniem?

Odpowiedź nie wydaje się taka oczywista. Nie zapomnę wyrazu zażenowania i politowania na twarzy parającego się kognitywistyką kolegi w reakcji na moje pytanie, czy uważa, że badania nad mózgiem to bezwzględnie najciekawszy obszar dociekań w tej dziedzinie. Wybitniejsi krytycy nie pogardzają jednak regularnym udziałem w debacie nad tezami, które najdobitniej ekspo- 
nują poznawczą rolę otoczenia; do grona tego należy między innymi Kenneth Aizawa, Robert Rupert, William Bechtel (Adams i Aizawa 2001: 44-64; Bechtel 2008: 155-170; Rupert 2013).

Czy elementy otoczenia mogą dosłownie brać udział w procesach poznawczych? Czy procesy te wykraczają poza granice naszych głów? Gdzie w takim razie leżą granice tego, co poznawcze? Czy aby nie posługujemy się tą kategorią w sposób nieuprawniony? Do odpowiedzi na te pytania w pewnej mierze przyczynia się praca Davida Kirsha „Myślenie za pomocą reprezentacji zewnętrznych" (2014). Swoimi uwagami natomiast chciałbym odbiór tej pracy trochę uzupełnić, a trochę też skomplikować.

\section{Rozproszenie i oferty}

Badania nad reprezentacjami zewnętrznymi (których naturę i rolę omówiłem już szerzej w: Wachowski 2014) wpisują się w szerszy horyzont badań nad poznaniem rozproszonym. Za twórcę tego nurtu badawczego zwykle uważa się Edwina Hutchinsa, autora książki „Cognition in the Wild” (1995) - najbardziej chyba znanej pracy $w$ tej dziedzinie. Teoria poznania rozproszonego, zaliczana do alternatywnych nurtów kognitywistyki obok takich teorii jak ucieleśnienie, teoria umysłu rozszerzonego czy enaktywizm, zajmuje dość szczególną pozycję względem kognitywistyki klasycznej. W odróżnieniu od wymienionych teorii (w większości ich wersji) nie neguje modelu obliczeniowego ani teorii reprezentacji umysłowych; a przy tym niespecjalnie odnosi się do problematyki umysłu jako takiego, koncentrując się raczej na procesach poznania oraz systemie poznawczym. Posiada jednak inne elementy przynajmniej z pozoru zasługujące na miano radykalnych. W jej świetle systemem poznawczym jest aktywna struktura złożona z podmiotów działających (zwanych również agentami) oraz pozapodmiotowych części otoczenia, a więc na przykład z człowieka (grupy ludzi) i zestawu artefaktów istotnych w danym procesie poznawczym. Ten ostatni, jak można się już domyślać, nie przebiega wyłącznie w głowie podmiotu, ale między nim a pozostałymi komponentami opisanego systemu, zwanego rozproszonym systemem poznawczym. System taki ma również swoją pamięć zdeponowaną w elementach otoczenia, swoje zewnętrzne przetwarzanie obliczeniowe, jak i swoje reprezentacje poznawcze. Praw i mechanizmów, które funkcjonują w tym systemie, nie sposób zredukować do tych, które rządzą poszczególnymi jego komponentami, wliczając w to również podmioty ludzkie. Dobrym przykładem takiego „zewnętrznego” i tym samym wewnątrzsystemowego rozwiązywania problemu badawczego może być korzystanie na statku z mapy nawigacyjnej (używanej na zasadzie analogowego komputera), która z powodzeniem scala rozproszoną, potrzebną w danym momencie wiedzę (Hutchins 1995: 61). 
W świetle powyższych informacji zrozumiałe będzie już to, że w rozwój badań nad poznaniem rozproszonym wnieśli istotny (bezpośredni lub pośredni) wkład zarówno kognitywiści i psychologowie, jak i badacze społeczni, między innymi tacy jak Bruno Latour (Hutchins 2001).

Drugą dziedziną, o której warto wspomnieć w kontekście tematu pracy Kirsha, jest psychologia ekologiczna. Wiążą się z nią pionierskie badania Jamesa J. Gibsona (1979) i - przede wszystkim - wywiedziona z nich teoria afordancji (inaczej: ofert). Przez afordancje - mówiąc w dużym skrócie - należy rozumieć pewne nieredukowalne właściwości środowiska danego podmiotu poznającego, które to środowisko owemu podmiotowi „oferuje”, „podsuwa”, zawiera jako swoistą prowokację do określonego działania. Te dyspozycje do działania postrzegane są przez podmiot bezpośrednio, chociaż - tłumacząc za Gibsonem - nie mają charakteru ani obiektywnego, ani subiektywnego. Ich natura jest „ekologiczna”, związana z danym środowiskiem i jego użytkownikiem, a przez to relacyjna, jak chcą niektórzy psychologowie ekologiczni. Przy czym kategoria środowiska obejmuje tutaj zakres dość szeroki, bo od poziomu biologicznego po kulturowy. Podłużny wijący się kształt już od czasów prehistorycznych budzi w nas pewne odruchy i przejawy ostrożności odpowiednie do ryzyka kontaktu z (być może niebezpiecznym) wężem. Natomiast zielony kolor sygnalizacji świetlnej, mimo że kierowca reaguje na niego raczej bezrefleksyjnie, wiąże się już z pewną konwencją społeczną.

Reasumując: jeżeli już mamy z jednej strony strukturę złożoną z podmiotów na przykład ludzi - i innych elementów otoczenia, a wszystko to powiązane istotnymi poznawczo relacjami (czyli rozproszony system poznawczy), a z drugiej strony - zdolność tych elementów otoczenia do wyzwalania w określonych podmiotach określonych działań (czyli zjawisko afordancji), to naświetlenie miejsca i roli reprezentacji zewnętrznych powinno przyjść teraz bez większego trudu.

\section{Gwiazdy głupsze}

W odróżnieniu od wewnętrznych reprezentacji umysłowych pojęcie reprezentacji zewnętrznych wydaje się tak oczywiste, tak banalne, a przy tym odniesione do tak różnorodnych desygnatów, że może sprowokować nawet machnięcie ręką i skwitowanie, że reprezentacją taką jest praktycznie wszystko. Może nią być bowiem symbol, znak, oznaka, uwidoczniona relacja lub struktura, jak i materialna „próbka” jakiegoś elementu naszej rzeczywistości.

No dobrze - stwierdzi oponent - gdy zechcę zaakcentować ważną informację w tekście, zaznaczę ją podkreśleniem; jeżeli nie zechcę użyć słów w celu nazwania jakiejś rzeczy podczas rozmowy, zarysuję jej kształt palcem w powietrzu; a jeśli chciałbym wreszcie nie zapomnieć o wykorzystaniu do obiadu produktu ze zbliżającym się terminem ważności, położę go rano na widocz- 
nym miejscu, żeby przypomnieć sobie o tej sprawie zaraz po powrocie z do$\mathrm{mu}$. Oto cała historia o używaniu reprezentacji zewnętrznych jako markera, znaku i tak zwanej pamięci zewnętrznej.

Otóż - nie. Jak pokaże nam Kirsh, nie jest to cała historia. Niewątpliwie powyższe przykłady zwracają uwagę na skuteczność posłużenia się reprezentacjami zewnętrznymi. Natomiast nie akcentują wyraźnie drugiej zasady, dla której często warto z nich korzystać - mianowicie wydajności. Jak podkreśla autor „Myślenia za pomocą reprezentacji zewnętrznych”, procesy poznawcze realizowane są w sposób najtańszy z możliwych. To zgodnie z tą tendencją niemal analogiczną do prawa grawitacji - tak często skłonni jesteśmy opuszczać nasze umysłowe sanktuaria, nasze mózgi w naczyniach, inaczej nie byłoby najmniejszego powodu, dla którego mielibyśmy się trudzić angażowaniem naszej cielesności oraz materialności otoczenia w akty przypominania, komunikacji, uczenia się i tak dalej (na pewno hasło „ruch fizyczny to zdrowie” nie ma aż takiej mocy sprawczej).

To na mocy zasad skuteczności i wydajności wspomagamy się otoczeniem w zapamiętywaniu, ale i w redukowaniu złożoności nadmiernie skomplikowanych problemów (z matematycznymi włącznie), w ułatwianiu sobie analitycznego wglądu w te problemy dzięki wizualizacjom. Przy tym wszystkim Kirsh ciągle opiera różnorodny dobroczynny potencjał reprezentacji zewnętrznych na dość prostych, wręcz banalnych ich właściwościach. Nie mają drugiego dna, nie służą do sztuczek, nie ma tu żadnej magii (chociaż w pewnym momencie autorowi temu wyrywa się porównanie fizycznego działania w świecie do czegoś magicznego). Jak czytamy w przytaczanej pracy: „Rzeczy w świecie zachowują się inaczej niż rzeczy w umyśle. Na przykład reprezentacje zewnętrzne są rozciągłe nie tylko w czasie, ale również w przestrzeni" (2014: 105). Rozciągłość $\mathrm{w}$ przestrzeni - jakże nieodkrywcze spostrzeżenie, prawda? Ale konsekwencje - jakże potężne. Zewnętrzne reprezentacje problemu to właściwie jedyny sposób, w jaki można się nim podzielić z innymi, zakomunikować go, wspólnie rozwiązywać. To również owa rozciągłość w przestrzeni pozwala na identyfikację etapów, wzorów, egzemplarzy i tak dalej - a więc na coś, co przy próbach odtwarzania w umyśle zaowocowałoby co najwyżej takim procederem jak nasenne liczenie owiec. Podobnie duże znaczenie okazuje się mieć eksternalizacja zadania dla kreatywności.

Poza prostymi, znanymi z życia i przez to szczególnie cennymi przykładami pojawiają się w pracy Kirsha odwołania do cudzych prac badawczych. Tutaj jednak należy wykazać się pewną (minimalną) ostrożnością - w odniesieniu do zmiennej wartości takich egzemplifikacji. Pisząc o trudnościach (bliskich niemożliwości) odkrycia wieloznaczności form jedynie wyobrażanych w odróżnieniu od tych zwizualizowanych, autor ten powołuje się na artykuł Deborah Chambers i Daniela Reisberga (1985: 317-328) przytaczany już przez siebie w przeszłości. $\mathrm{W}$ międzyczasie jednak pojawiły się inne prace badawcze, 
które podały wątpliwość niektóre wnioski Chambers i Reisberga (np. Peterson i in. 1992: 107-123). Taka jest niestety ogólna cena rosnącej liczby, czasami wręcz natłoku badań i raportów badawczych w niektórych dziedzinach, których regularna kontrola (że już nie wspomnę o lekturze) staje się niemożliwa.

Pozostając w temacie kreatywności: autor „Myślenia za pomocą...” pisze również o dobrodziejstwie korzystania $\mathrm{z}$ reprezentowania zewnętrznego w przypadku komponowania muzyki, przy czym ma tutaj na myśli zarówno jej dosłowne słuchanie oraz odgrywanie, jak i wgląd i operacje na notacjach muzycznych. To cenne uwagi, których doskonałym przedłużeniem może być lektura biografii znanych kompozytorów: Igora Strawińskiego, Sergiusza Prokofiewa, Antona Weberna i innych. Pokazują one bowiem kompleksowe powiązanie stosowanych praktyk z osobowością czy ogólnym stylem życia. Komponowanie przy instrumencie (na przykład fortepianie) niewątpliwie może być z różnych względów korzystne, jako że - zgodnie ze spostrzeżeniami Kirsha i nie tylko - słyszana struktura dźwiękowa rządzi się innymi prawami niż symulowana w głowie. Ale wędrując palcami po klawiszach, jest się zdanym na możliwość pewnych odruchów, zapamiętanych układów, mimowolnie przywoływanych konwencji. Od takich pokus kompozytor może się wyzwolić, przenosząc się od klawiatury do pisania muzyki; ale przecież i tam czaić się mogą pokusy form już wcześniej przepracowanych. Zapewne $\mathrm{z}$ tych między innymi powodów komponowanie utworów dodekafonicznych okazało się dosyć żmudną procedurą, bo skrępowaną niemożnością powtórzenia dźwięku przed wykorzystaniem całej skali dwunastu tonów. Pewne zalety wiążą się więc również z opracowywaniem kompozycji w głowie. A z drugiej strony pamiętać należy o tym, że komponowanie, a jeszcze bardziej instrumentacja (szczegółowe rozpisanie utworu na instrumenty) w oderwaniu od instrumentu może prowadzić do znacznych trudności wykonawczych, niekiedy przekraczających fizyczne możliwości wykonawcy, co też się zresztą zdarzało (zob. np. Erhardt 1978; Jaroszewicz 1983; Stawowy 1992).

Autor „Myślenia za pomocą...” odwołuje się do afordancji jako zjawiska umożliwiającego bezpośrednią, często pozarefleksyjną interakcję między reprezentacją zewnętrzną a podmiotem. Warto wspomnieć tutaj o próbach bardziej kompleksowego opracowania zagadnienia relacji między tymi reprezentacjami a afordancjami. Próby takiej podjęli się Jiajie Zhang i Vimla L. Patel, proponując ujęcie afordancji jako rozproszonych reprezentacji „rozpiętych” między otoczeniem a organizmem (Zhang i Patel 2006: 333-341). Z drugiej strony literatura tematu pokazuje, jak afordancje funkcjonujące $\mathrm{w}$ rozproszonych systemach poznawczych można różnorodnie wykorzystywać, jak i projektować (Woods 2008; Elm i in. 2008; Norman 1993). Wreszcie chciałbym tutaj wspomnieć o sferze tak zwanych afordancji kanonicznych: reprezentacje zewnętrzne funkcjonują również w szczególnym kontekście praktyk kulturowych, gdzie afordancje nie ograniczają się do relacji pary podmiot-przedmiot, 
ale są zależne od pewnych konstelacji tak przedmiotów, jak i zdarzeń (Costall 2012: 296-304; Costall i Richards 2013).

Na koniec uwag do „Myślenia za pomocą...” przywołam istotne zastrzeżenie Kirsha. Podkreśla on, że w żadnym wypadku nie chodzi mu o wykazanie absolutnej nieodzowności i niezastępowalności reprezentacji zewnętrznych w pewnych dziedzinach naszej aktywności. Wyniki badań nad nimi nie są anonsowane hasłami typu: „Hurra, wykazaliśmy granice możliwości mózgu”. Powtórzmy: korzystanie z tych reprezentacji rządzi się zasadami wydajności i efektywności. Nie stoi ono w sprzeczności z faktem, że istnieją wyjątkowe jednostki zdolne wykonać skomplikowane operacje wyłącznie w swoich umysłach, bez potrzeby interakcji z otoczeniem i przerzucania na nie części kosztów procesu - tak jak to zazwyczaj czyni większość osób. Słowo „zazwyczaj” jest tutaj kluczowe. Nasze umysły zdolne są oszczędzać swoje moce, korzystając z tego, co można wykonać na zewnątrz. I takie sformułowanie zjawiska nie powinno brzmieć szczególnie kontrowersyjnie.

\section{Czarne dziury}

Do odpowiednich wniosków dotyczących granic tego, co poznawcze, Czytelnik zapewne dojdzie już po lekturze przytaczanego artykułu Kirsha. Natomiast osobną kwestią pozostaje to, na ile przekonujący jest sam podział reprezentacji na wewnętrzne oraz zewnętrzne (nie wspominając już o reprezentacjach rozproszonych wspomnianych przy okazji badań nad afordancjami). Ów podział może nie być konsekwentny z co najmniej dwóch powodów: (1) Reprezentacje te funkcjonują jednak wewnątrz systemu poznawczego, wprawdzie rozproszonego, ale strukturalnie od nich nieodłącznego. (2) Nasza interakcja z reprezentacjami zewnętrznymi angażuje mimo wszystko tryb reprezentowania umysłowego (jeżeli pozostajemy tutaj na stanowisku niekontrowersyjnego reprezentacjonalizmu poznawczego) w zakresie samego już identyfikowania zewnętrznych elementów jako reprezentacji. Jednak nawet gdyby owa typologia miała się w ostatecznym rozrachunku nie utrzymać lub nie dojść do głosu w głównym nurcie kognitywistyki, to w pracach Kirsha i niektórych innych badaczy poznania rozproszonego zdążyła już odegrać całkiem pożyteczną rolę.

Chciałbym jeszcze tutaj uzupełnić egzemplifikację „Myślenia za pomocą...” w sposób może nieoczekiwany, ale chyba właściwie dopełniający obrazu rzeczy. Obraz ten bowiem dzięki Kirshowi prezentuje się dość sielankowo: oto podmiotowi z problemami poznawczymi, który znalazł się na łączce pełnej reprezentacji zewnętrznych, te ostatnie tak wdzięcznie pomagają, że pozostaje nam tylko zakrzyknąć: ależ byśmy się bez nich męczyli! 
Spójrzmy jednak też na to z... ciemniejszej strony. Zastanówmy się, ileż niedobrego zamieszania, zbędnego angażowania uwagi i aktywności (wszak afordancji nie da się wyłączyć pilotem) pochłaniają nam całe tabuny niepotrzebnych, przypadkowych, ubocznych, przeszkadzających reprezentacji zewnętrznych. Jeśli słyszeliśmy o cudownej pamięci (takiej czysto wewnętrznej) starożytnych, to pomyślmy - abstrahując od ich środków mnemotechnicznych - o tym, że szczęśliwie nie byli narażeni na wiele dekoncentrujących i dezaktywujących reprezentacji zewnętrznych, które uprzykrzają nam dzisiaj życie. Praktycznie każda większa ulica w mieście stanowi jeden wielki tunel atakujących nas reprezentacji nie tylko natury marketingowej. A jednak jakoś sobie $\mathrm{z}$ tym radzimy.

Znamiennych przykładów może dostarczyć oprogramowanie komputerowe regularnie doskonalone na potrzeby tak zwanego przeciętnego użytkownika, z którym niekiedy trudno się utożsamić. Osoba intensywnie korzystająca z edytora tekstów wie zapewne, jak przeszkadzać może graficzna ikonka „Opcje wklejania”, która pojawia się w tekście podczas wykonania zadania „kopiuj+wklej”, irytująco zasłaniając fragment pisanego tekstu. Innym przykładem przedobrzenia $\mathrm{w}$ zakresie projektowania może być nowa wersja popularnego systemu operacyjnego, najwyraźniej nastawiona na wykorzystanie w celach rozrywkowych i to głównie w tabletowych wersjach komputera, ale już chyba słabiej - w pracy naukowej. Skierowanie kursora zbyt blisko krawędzi ekranu wywołuje graficzno-tekstowe ikonki wyszukiwania, udostępniania, startu, urządzeń, ustawień, godziny i daty - co być może zadowala użytkownika w jakiś sposób upośledzonego lub potrzebującego częstego przełączania się między różnymi opcjami, natomiast na pewno nie ułatwia pracy wymagającej skupienia i jak najmniejszej liczby zbędnych bodźców. W najmniej odpowiednim momencie potrafią się również pojawić sygnalizacje dostępnych aktualizacji ${ }^{29}$. Oczywiście, z lepszym czy gorszym skutkiem, ale jednak i z tymi reprezentacjami zewnętrznymi potrafimy jakoś walczyć poprzez mobilizację rywalizujących z nimi naszych wewnętrznych mocy umysłowych. Przykłady takie można by mnożyć, także z dala od laptopa.

Praca Kirsha to szczególny rodzaj historii o tym, jak ludzie pomagają sobie w życiu reprezentacjami zewnętrznymi. Można by jednak napisać drugą historię: jak ludzie muszą w życiu walczyć z takimi reprezentacjami. A wtedy na kategorie wydajności i efektywności procesu poznawczego prawdopodobnie spojrzelibyśmy z zupełnie innej strony.

\footnotetext{
${ }^{29}$ Zapewne niektóre z tych opcji można wyłączyć, to jednak kolejna praca do wykonania (przede wszystkim wymagająca umiejętności nazwania tego, co chcemy wyłączyć, aby móc przeszukać źródła informacji).
} 


\section{Zakończenie}

Jak się wydaje, wyniki badań nad reprezentacjami zewnętrznymi są w stanie zainteresować również czytelników sceptycznie nastawionych wobec używania (rozumianego jako nadużywanie) kategorii tego, co poznawcze, przez rzeczników teorii poznania rozproszonego i psychologii ekologicznej. Kirsh z pozoru skupia się na prostych, nieraz wręcz banalnych aspektach procesów rozwiązywania problemów poznawczych. Ale z czego innego właściwie składają się nasze najbardziej zaawansowane poznawczo przedsięwzięcia? Przywołam tutaj kontrowersyjnego dla kognitywistyki Latoura: „W szesnastym wieku nie pojawił się żaden nowy człowiek, a we współczesnych laboratoriach nie pracują wcale mutanci o rozrośniętych mózgach” (Latour 2012: 208). Czy pod pojęciem wybitnego naukowca nie kryje się przypadkiem dobra (na własny użytek) organizacja pracy, odpowiednio wyposażone laboratorium, optymalnie skoordynowany zespół współpracowników?

Trudno oponować, jeśli na maskotkę kognitywistyki wybrano już (przypominający w najlepszym wypadku orzech włoski, w najgorszym - ekskrementy) mózg. Gdybym jednak miał wskazać na dumne symbole ludzkiego intelektu, wybrałbym raczej pewne artefakty - w rodzaju kartki i ołówka, cyrkla, liczydła, astrolabium czy nawet (niechże już będzie) komputera. A pewnie ani w jednym, ani w drugim przypadku zwolennicy bardziej natchnionych wizji ludzkiego ducha nie będą zbyt zadowoleni.

\section{Literatura}

Adams, F. i Aizawa, K. 2001. The bounds of cognition. Philosophical Psychology, Vol. 14, No. 1: 44-64.

Bechtel. W. 2008. Explanation: Mechanism, Modularity, and Situated Cognition. P. Robbins i M. Aydede, red. The Cambridge Handbook of Situated Cognition. Cambridge: Cambridge University Press: 155-170.

Białoszewski, M. 1956/1987. O obrotach rzeczy. Utwory zebrane. Tom 1. Warszawa: Państwowy Instytut Wydawniczy: 60.

Chambers, D. i Reisberg, D. 1985. Can mental images be ambiguous? Journal of Experimental Psychology: Human Perception and Performance, 11: 317-328.

Costall, A. i Richards, A. 2013. Canonical Affordances: The Psychology of Everyday Things. P. Graves-Brown, R. Harrison i A. Piccini, red. The Oxford Handbook of the Archaeology of the Contemporary World, Oxford: Oxford University Press: 82-93.

Costall, A. 2012. Afordancje kanoniczne w kontekście. Przeł. K. Bielecka. Avant, III, 2/2012: 296-304.

Elm, W.C., Potter, S.S., Gualtieri, J.W., Easter, J.R. i Roth. E.M. 2008. Applied Cognitive Work Analysis: A Pragmatic Methodology for Designing Revolutionary Cognitive Affordances. E. Hollnagel, red. Handbook of Cognitive Task Design. Mahwah, New Jersey: Taylor \& Francis e-Library: 357-382. 
Erhardt, L. 1978. Igor Strawiński. Warszawa: Państwowy Instytut Wydawniczy.

Gibson, J.J. 1979. The Ecological Approach to Visual Perception. Boston: Houghton Mifflin.

Good, J. 2007. The Affordances for Social Psychology of the Ecological Approach to Social Knowing. Theory \& Psychology, Vol. 17(2), 265-295.

Hutchins, E. 1995. Cognition in the Wild, Cambridge: MIT Press.

Hutchins, E. 2001. Distributed Cognition. N.J. Smelser i P.B. Baltes, red. The International Encyclopedia of the Social and Behavioral Sciences: 2068-2072. Cambridge: Elsevier Science Ltd.

Jaroszewicz, J. 1983. Prokofiew. Kraków: Polskie Wydawnictwo Muzyczne.

Kirsh, D. 2014. Myślenie za pomocą reprezentacji zewnętrznych. Avant, V, 1/2014: 94125.

Latour, B. 2012. Wizualizacja i poznanie: zrysowywanie rzeczy razem. Przeł. A. Derra i M. Frąckowiak. Avant, III, T/2012: 208-257.

Norman, D.A. 1993. Things That Make Us Smart: Defending Human Attributes in the Age of the Machine. Boston, MA: Addison-Wesley Longman Publ. Co., Inc.

Peterson, M.A., Kihlstrom, J.F., Rose, P.M. i Glisky, M.L. 1992. Mental images can be ambiguous: reconstruals and reference-frame reversals. Memory \& Cognition, 20(2):107-123.

Rupert, R.D. 2013. Distributed Cognition and Extended-Mind Theory. In B. Kaldis, red. Encyclopedia of Philosophy and the Social Sciences. Los Angeles: SAGE Publications.

Stawowy, L. 1992. Webern. Kraków: Polskie Wydawnictwo Muzyczne.

Wachowski, W. Reprezentacje zewnętrzne w sporze o eksternalizm. Przegląd Filozoficzno-Literacki. Kognitywistyka. Reprezentacje, 2014 (w druku).

Woods, D.D. 2008. Discovering How Distributed Cognitive Systems Work. E. Hollnagel, red. Handbook of Cognitive Task Design. Mahwah, New Jersey: Taylor \& Francis e-Library: 37-54.

Zhang, J. i Patel, V.L. 2006. Distributed cognition, representation, and affordance. Cognition \& Pragmatics, 14(2): 333-341.

\footnotetext{
Abstract

The present text is a kind of an introduction to the article "Thinking with external representations" by David Kirsh. The author focuses on the contribution of external representation to the very structure of the cognitive proces.

Keywords: external representations; distributed cognition; cognitive system; affordance; interaction; externalism; Kirsh.
} 